\title{
Antiquity of Nepali Mathematics
}

\section{E. R. Acharya (PhD)}

Central Department of Education(Tribhuvan University),University Campus, Kirtipur, Kathmandu, Nepal

\author{
er_acharya@yahoo.com
}

\begin{abstract}
The mathematics developed before the written recorded history is called antiquity of mathematics. It is the fundamental basis for the historical developments of mathematics. It has greater significance in understanding the people, culture and mathematics in totality. The mathematics is practices very early as old as the human civilization and it is also true for in context of Nepal. In High Himalayan Region there are so many symbols of very early mathematics either as rock art or formation of chambers as administrative room. The utensils, fossils and physical contractions of Zhong Kiore Cave of Mustang as evidences. The aim of this paper is to exploration antiquity of Nepali mathematics.
\end{abstract}

Keywords: Antiquity, Prehistory, Archeology, Himalayas, Mathematics

\section{INTRODUCTION}

Antiquity is the basic foundation of history and civilization of each society. It has greater significance in understanding the people, culture, rituals and mathematics in totality. Here it is concern to Nepal. Nepal lies on the laps of the large ranges Himalaya before millions years ago it laid under the Tethys Sea. Due to millions years' geological and tectonic movement and geographical disasters the level of Tethys Sea became higher and higher and form folded rocks and mountains. In course of time it was changed as high Himalayas, Lower Mountain, Peasant Valleys and large plains in southern regions continuously. Consequently, various water-lakes, snowflakes, rivers were formed, like Mahendra Lake, Gosaikunda, Fewa Lake and Kathmandu Valley, etc.

The Himalayas are among the youngest mountain ranges on the planet. Their origin dates back to the Upper Cretaceous period, 70 million years ago. Due to the plate tectonic movement, the Himalayas are rising by about $5 \mathrm{~mm}$ per year, making them geologically active and geographically significant. For Millions of years the Valleys in Kathmandu, Pokhara, Dang, and Surkhet were covered with water. From These valleys time to time water is running out and the other side decantation takes place. After flowing water these lands were drying and algae, and different plants, animals are appeared. The fossils of billions of years old of elephant and Rhino found at Dang proved that the existence of prehistoric animals in Nepal.

\section{REVIEW OF LITERATURES}

Nepal lies at the interface between the two giant economic and scientific centers of human civilization, India to the south Tibet and China to the north. In the beginning, there were primitive people of indigenous origin scattered in different parts of the country with hunting-gathering mode of production and primary stage of cultural development, for example rock art in kak Nyingba. The presence of nomadic people like Kusundas, Chepangs and the Rautes in different isolated pocked of the country indicates the existence of prehistoric men and the culture in Nepal and the fossils of prehistoric Hominoid-Ramapithecus of eleven million years old that found at the foot of Siwalik range in few years ago at Tinau River, Butwal Sub Metropolitan.

About prehistoric mathematics education, Shreshtha stats as, 'Mathematics was, is and is going to be one of the basic areas of knowledge. Everyone is familiar with its all-round use and importance. For a long time since the 
ancient times, teaching and learning of mathematics continued to remain without being separated from the main body of mathematical knowledge [16]. Pant, S.R. (Mathematics in Nepal, 2004) has given a brief sketch as a historical analysis about the development of Mathematics in Nepal [10].

Sharma said that the period up to Lord Buddha is called historic period whereas the periods previous to that should be called proto-historic and pre-historic. In prehistoric period, human lived in Caves, forests and thickets of Mahabharata range, for example Upper Mustang Cave [14].Jacqueline pointed out the most important facts about prehistoric man in Nepal by age and by sex; complete skull and any attached/corresponding axial elements that articulated well with it; bones were found in somewhat discrete piles...; through his report. In this journal Jacqueline explained different parts of the human body found in upper Mustang. It is as the milestone for the proofs of existence of prehistoric man in Nepal [8].

Shrestha said that 'Mount Everest remains as the symbol of Nepal-China relationship. The Himalayan Mountain being the home of early man (hominids) the relationship of the two countries continued from prehistoric proto historic and historic period. Nepal's relation with her northern neighbor is deep rooted because many ethnic communities of Nepal are of Mongolian origin...' He expressed his views on archaeological excavation and explorations for dealing with the scientific study of human activities on the earth relating to different disciplines of learning [15]. Shrestha, Simons and other 12 authors explained the prehistoric burial site which is made by man 2000 years ago. This is a unique prehistoric burial site in the artificial Cave system of Muktinath Valley, 3600 metres above the sea level.

Sharma has given a brief note on the seminar on high mountain archaeology of Nepal. This brief note is the reliable source for prehistoric man in Nepal together different disciplines [14]. Uddhava Acharya has given a valuable recognition of archaeological scenario of Pharping, where different fossils, Quartzite, Paleolithic age's elephant's bone of femur were found. This indicates the origin of early animals and their developments in Nepal [3].

Mebrak Cave Dzong River addressed prehistoric records of man and their mathematics. The 28 samples from burial Cave were radiocarbon-dated and their different laboratories and calibrated with dendrochronological data to ascertain the absolute age of the mummies. The result shows that the Cave was built in between 400 B.C. to 50 A.D.

Simons, Schon' given the Cave system of 'Chokhopani' in Mustang period -1, throughout the newly established, eponymous 'Mebrak' in Mustang period-2. The authors analyzed these evidences by archaeological, anthropological treatments and concluded that the Cave burial complex excavated in Mebrak should be so unique as yet without parallel at the time of first Millennium B.C. [5]

The people's participation in the management of local affairs in Southern Mustang in 19th and 20th centuries with indicating the various sites of Southern Mustang and her local administration and ruling. These facts show the redeveloped condition of Mustang that relates the super existence of prehistoric man in Mustang.

Simons, Schön, and Shrestha have given the "Preliminary Report on the 1992 campaign of the team of the institution of prehistory, University of Cologne" through the excavation of Mustang about the high mountain region of Mustang District containing numerous multi-storey Cave system that were dug by men into the faces of the rock massifs situated alongside the riverbeds. Here the authors described the physical conditions of different Caves with fossils of dead bodies [7].

Pradhan says that, 'every animals are either near or far distant; they are inter-related.' He described the features of different Pithecus and the relationship among them. And he announced that the same species is given to each of them. Similarly the name is given 'Butwal Ramapithecus' obtained at Butwal of Nepal. He expressed his thinking about tradition of human development in Nepal [12]. Related evidences of prehistoric man in Nepal and prehistoric Nepali mathematics forwarded below. 


\section{EXCAVATION REPORTS}

To express the evidences of existence of Prehistoric man in Nepal various Excavation reports are found among them few are addressed here. Gudrun Corvinus explains that, it must have been an adventurous life that she led during her 20 years of research in the Siwalik foothills of Himalayas in Nepal. Corvinus was certainly not an armchair anthropologist. Before Corvinus ventured into the field, there was no definite proof of prehistoric cultures in Nepal except for some Neolithic axes. The German archaeologist was qualified for the task of mapping this uncharted territory not only through her studies in geology but also in prehistory at the University of Tübingen. In the 1970s, Gudrun Corvinus was in Ethiopia on the team with Donald Johanson that unearthed the skeleton of our upright walking ancestor 'Lucy'. Her remains were classified as a more than 3 million years old Australopithecus aphaeresis [7].

The indigenous population of the Dun Valleys is Tharus, traditional peasants. During the last 50 years, the Tharu population of the fertile plains of the Terai and the Dun Valleys was settled by groups of Brahmins, Khas and Chhetris who bought up the best land for farming, turning the indigenous Tharus into labourers. The residential areas of the newly arrived and the original groups are strictly separated in the villages. She admired their longhouses with thatched roofs, their storage jars and the Tharu women carrying water vessels on their head. In Nepal the Deokhuri valley is still known for its fine pottery.

In November 1997 the German archaeologist discovered what she calls "the finest hand axe ever found in Nepal." It came to light in Central Nepal on the Satpati Hill and is probably more than 730,000 years old. This would be the oldest evidence of an Acheulian culture on the Indian subcontinent. Gudrun Corvinus can be credited with having demonstrated migration from India into the region of today's Nepalese Siwalik range from the Pleistocene.

Further East in the Siwaliks, the researcher unearthed the remnants of a Mesolithic culture, the Patu Industry which flourished about 7,000 years ago at the Rato River. This culture from the early Holocene is more akin to the Southeast Asian Hoabinhian industry, named after a place of findings in Vietnam. The prehistoric artifacts collected during this project are housed at National Natural Museum, Chhauni.

Prehistoric man is known to have lived in many parts of the world. Many people, including historians of Nepal, are found to be not so keen in telling something about the pre-historic man of Nepal. They remain silent by accepting whatever stories are being told or narrated in myths, legends, and epics like the Ramayana, the Mahabharata and other Buddhist literature. They, quite often, try to escape by saying people from neighboring countries came to Nepal, settled gradually and finally began to rule. In many occasions, they rely on Gopal Vansavali as the principal source of early history of Nepal. This state of affairs is rather very unfortunate. We, therefore, try to examine the situation from logical and geo-archaeological points of view.

This requires, at least, a first glimpse geography and Archeological records of Nepal. Such records are found in Banerjee's paper 'Discovery of the Remains of Prehistoric Man in Nepal'; Gudrun's paper 'First prehistoric remains in the Siwalik Hills of Western Nepal'.

In 1953 A. D., Nepal government started its archaeological activities by establishing the Department of Archaeology. Archaeological excavation of some places of Kathmandu began in 1965 A.D. Antiques and pottery, terracotta figurines, coins and seals bearing various inscriptions found led archaeologists to believe in the existence of cultural tradition of the period (800 B.C - 300 B.C.). Although started very lately, paleontological and prehistoric exploration made during 1980 A.D. near Butwal in Nepal did produce one of the most sensational results of archaeological investigation.

The concept for the existence of animals in the earth is different. According to American anthropologist, the animals (living beings) found in the earth are same in the origin. This theory is generalized as "Theory of Eternity of Present Condition)'. The second theory is 'Diving Theory or Special Theory of Creation'. This theory 
is mostly popular one. Mostly people pursuit that the Diving Energy. Similarly other different theories are in existence in the study of prehistory of man and human civilizations. Theory of Catastrophic is also a theory of development

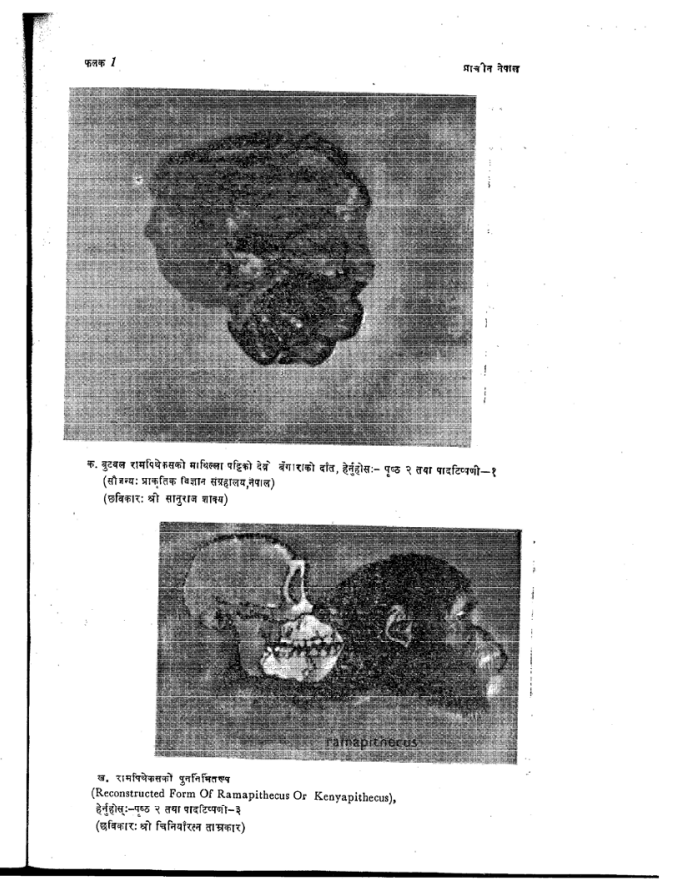

\section{Human Remains in Unearthed Cave}

Experts digging into the Mebrak Cave in Lower Mustang (Nepal) have unearthed new clues, which could potentially unravel a significant portion of human history dating back to 450 BCE. A team of experts including those from the Department of Archaeology, who have been studying two unique corpses recovered from Mebrak Cave complex in Muktinath Valley of Lower Mustang, say that shocking features of the corpses are drawing them closer to discovery of a peculiar prehistoric culture.

Shrestha said that during the 1992-1997 excavation carried out in other parts of Mustang "Ceramic vessels filled with food offered to the deceased were found into the grave chamber, pointing towards a very peculiar culture that is not in practice now. ('Edited from The Kathmandu Post (28 December 2011)). The 'homoerectus' pre-historic man diversified from Asia to Europe and developed new culture there [17] [4].

Neanderthal man is the real pre-historic origin of man. Its height is 5' ${ }^{\prime \prime}$, large head, jaws are little bit small, long facial appearance, flats and pointed nose, and bones on chicks are also suitable as new man (i.e., modern man). Capacity of brain is higher than 1450 C.C. Today's man's capacity of brain is 1350 .C.C. The same features are found in the Nepalese people and neighborhoods of Nepal. Every year so many think tank and brilliants migrating from Nepal to European countries indicated the brain capacities [12].

Nepal's Mustang Cave leads to Prehistoric development of Nepalese society and man in Nepal. The evidences are explained by Tom Dedroog. Nepali experts digging into the mysteries of the famous Mebrak Cave in Lower Mustang in western Nepal have unearthed new clues, which could potentially unravel a significant portion of human history dating back to $450 \mathrm{BC}$.

On the basis of the recorded evidences found at different excavations reports at Mustang, Lumbini, Dang, 
Kathmandu, Danda, Jhapa, etc and on the basis of religious, myths, legends, epics and from study of the written reports there is evidence of prehistoric man in Nepal. No doubt all researches are very scientific and reality base with multi-dimensional approach but there are lacking Mathematical interpretation and approach although they contains mathematical symptoms, because mathematics is everywhere and every things is in mathematics.

\section{Antiquity of Nepali Mathematics}

Mathematics relies on logic and creativity, and it is pursued both for a variety of practical purposes and for its intrinsic interest. For some people, and not only professional mathematicians, the essence of mathematics lies in its beauty and its intellectual challenge. For others, including many scientists and engineers, the chief value of mathematics is how it applies to their own work. Because mathematics plays such a central role in modern culture, some basic understanding of the nature of mathematics is prerequisite for scientific literacy. To achieve this, students need to perceive mathematics as part of the scientific endeavor, comprehend the nature of mathematical thinking, and become familiar with key mathematical ideas and skills.

Mathematics, now, is considered as a social creation. Culture is the contributing factor for the development of Mathematics. Mathematics plays an important role in the advancement of culture and civilization. So development of culture and Mathematics contribute each to other for their advancement. The application of Mathematics is no less important from ancient society to the modern society to make temples, roads, pyramids, cities and plans of economic development, etc.

The numeral system was developed as symbols in Lichhavi period. Beyond that the records of formal mathematics is generalized as prehistory of mathematics. One of such well-developed numeral systems is Lichhavi numeral system in ancient period was gradually developed not accidently, before Lichhavi period, human civilization were established by historical documents. Chinese said that Nepali had unique and fast calculation system which makes 'calendar' very fast. On the basis of these evidences in mathematics refers to existence of prehistoric mathematics in Nepal can be justified.

Naya Raj Pant has given brief description about the pronunciations system of Vedic numeral and corresponding to it the writing system of numbers in Lichchhavi Era, in Nepali. The actual date of Vedic period is not clearly defined and in Vedas the number system was mentioned but it may be prehistoric period. The Nepalese Hindu civilization is as old as human development and human civilization. Thus, on the basis of Pants description of number system in different Era shows the early development of mathematics. The word 'Vimshati' in Yajurveda indicates 20 based counting system. On the other hand indigenous Nepali mathematics is not written. It is transformed to their coming generations through rote practice [1].

\section{Evidence of Mathematics in Ancient Nepal}

In National Museum, Chhauani, Department Archeology and National Archive (Abhilekhalaya), we got some evidence which is related to mathematics as Mustang Cave, hand axe, some pots. This shows that mathematics was developed in prehistoric period but do no research has used in mathematical approach. According to Prapannacharya, development of source of science (i.e., mathematics) stepped down from Mt. Everest to the world [13].

About prehistoric mathematics education, Shreshtha stats as, 'Mathematics was, is and is going to be one of the basic areas of knowledge. Everyone is familiar with its all-round use and importance. For a long time since the ancient times, teaching and learning of mathematics continued to remain without being separated from the main body of mathematical knowledge.' Further he explained as, today, it has become a well-recognized field of knowledge. In the beginning, mathematics education consisted merely of teaching and learning of how to use 
fingers for counting or setting aside one pebble for each sheep or making a notch on a stick or the like. Whatever mathematics taught or learnt in those days was done orally. With the ability to write or with the development of written numbers or numerals and skill of drawing figures, mathematics education took a turn. Record keeping, numerical manipulation and pictorial representation of various human related activities became possible. In those early days, this much of knowledge was sufficient for men to become numerate Fingers are used either for counting or pointing. Counting began with fingers and digits refer to fingers [16].

That was one of the earliest recordings of a decimal numeral system in Vedic period but that was not written but only verbal. The use of the zero also proved that a 10 based positional numeric system was in use at that time. It is open to speculation how long before this date the decimal system, inclusive the zero, was invented. In $500 \mathrm{BC}$, the first known description of a binary numeral system was made by Pingala. He is the author of the chandah-shastra, the Sanskrit book on meters, or long syllables. While Pingala's system uses the symbols 1 and 2, Leibnitz (17th c.) uses 0 and 1, like the modern binary numeral system. The Pingala's prosody was also written by Halayoudha Bhatta in 10th century A.D. at Janakpur.

In Nepal there are more than 100 types of societies based in caste and so many ethnic groups, they have their own counting, ranking and measurement system. In this concept paper it is not possible to describe system of all societies. In short we claimed that this paper is able to aware for further searching prehistoric Nepali mathematics.

\section{FOSSIL OF HUMAN}
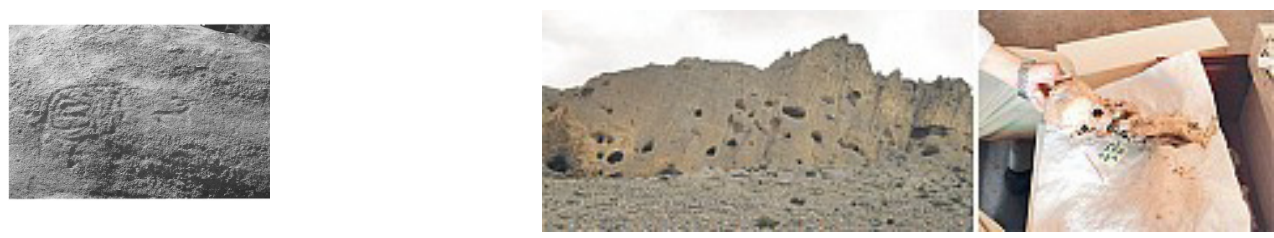

The Petro glyphs of Kak Nyingba are located north of the main range of the Himalayas in the middle course of the Kali Gandaki River at a height of 2,770 m. The surrounding landscape is that of an arid high mountain area with oasis like the petro glyphs were carved into flat sandstone banks abutting the Kali Gandaki River deserted settlement of Kak Nyingba, after which the rock art site was named, lies in the vicinity. The petro glyphs of Kak Nyingba were hammered or chiseled into the rock with simple stone tools, and partially ground and polished. There are the large number of symbolic representations as circle, half round, lines, geometric signs, and serpents. These structures represent the mathematical pattern [11].

\section{Mustang Cave}

Nepal's Mustang Cave leads to Prehistoric development of Nepalese society and man in Nepal. The evidences are explained by Tom Dedroog. Nepali expert digging into the mysteries of the famous Mebrak Cave in lower Mustang in western Nepal have unearthed new clues, which could potentially unravel a significant portion of human history dating back to $450 \mathrm{BC}$. The Cave structure shows the prehistoric mathematical construction.

The early mathematics was mostly geometry and arithmetic which are found in every constructions of Nepalese context. For example in the very remote area of Nepal, that is in Mustang at where the bamboo artifacts from Mebrak Cave (350 B.C.-50 A.D) show the use of geometrical concept, volumetric and concepts of area, that's why Nepalese people are rich in mathematics. The bamboo baskets, left by men in the Cave from Mebrak (16th century) show the developments of mathematical concepts on constructions of daily used utensils. The wooden drinking cups from Mebrak Cave (350 B.C.-50 A.D) show what? Mathematics! Actually construction is mathematics. The man made utensils on archaeological importance materials from Mustang Cave (i.e., Mebrak Cave), the grave goods taken out from the 'Chokhopani burial' Cave (in Nepali, Chihan gadiyako Gupha) (4th 
century B.C.-1st century A.D) show the existence of early man in Nepal also pointed out for the mathematical developments in Mustang.

The basis of modern arts and architecture and artifacts of Nepal is the preexistence of mathematics. The centre of gravity of any monuments and temples are maintained by mathematical treatments. For this we need mathematical concepts. The modern daily used instruments are developing gradually from the early used. The beauty appears on monuments, temples, houses or any construction based on mathematical operations. On each construction arts based on geometrical shapes, size and the ratios, ordering is present. The man made hand axes of stone found in Dang Deukhuri, Lubhu, Danda( Nawalparasi), Charikot (Dolakha), Khopasi (Jung Gaun), Jhapa are the evidences for the existence of prehistoric man in Nepal and her mathematics. These evidences were found by the German research team with Gudrun.

The corridors and rooms, mud, bricks in North and South Zhong Kiore Cave are well managed and based on geometrical shapes and sizes that indicate the mathematical concepts at that time. The followings are the utensils, fossils and physical contractions of Zhong Kiore Cave of Mustang given by Mohan Singh Lama.
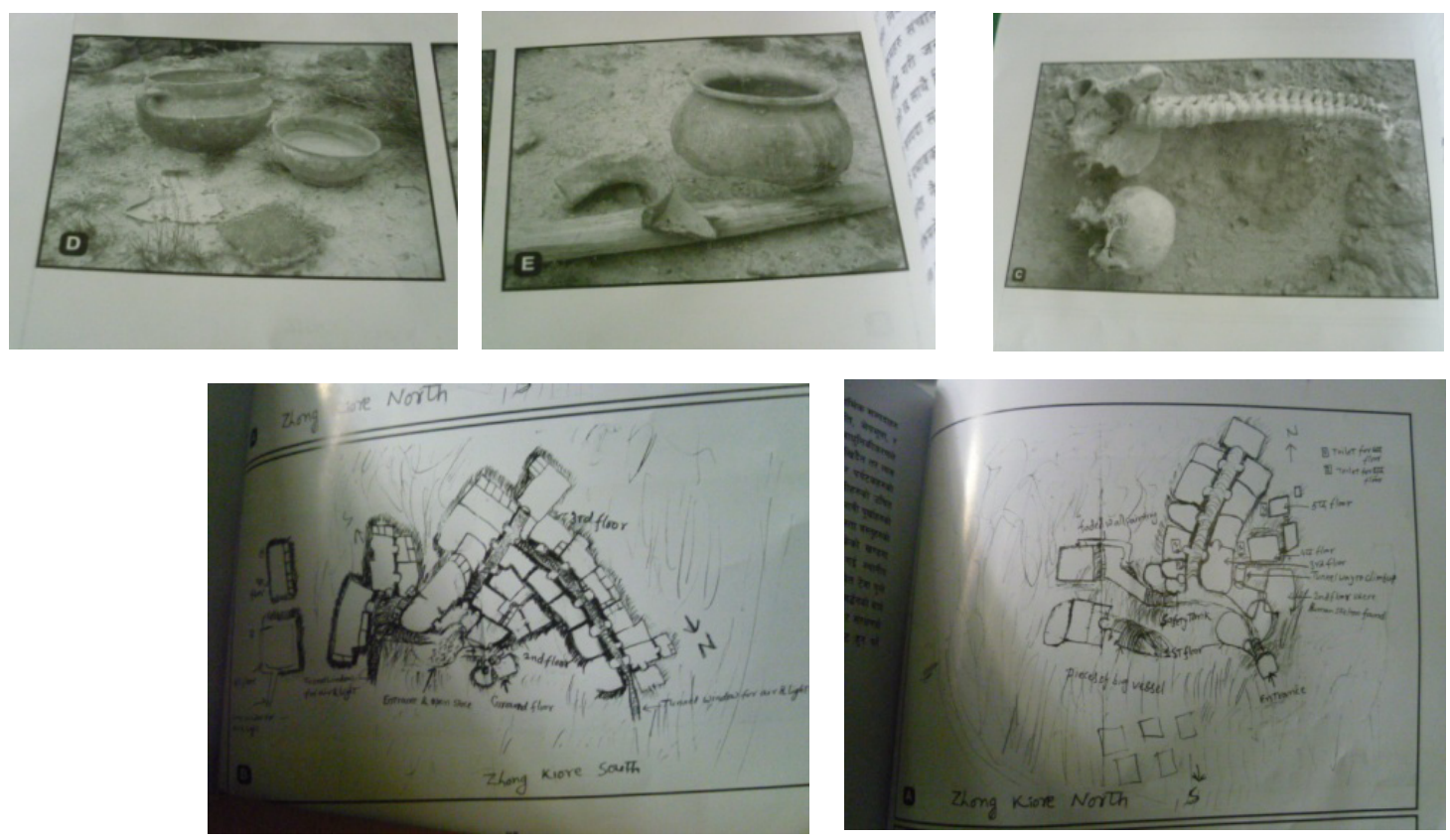

Darnal has explained the different Caves in Mustang; Mandala Cave, Phodaling (Goije Phu), Chukumau Dhakpu, Shaka Phu, Marchung, Tashe Kabung, Luri Cave, Tangya Kabung, Charang Cave, Dhakmar Cave, Chili Phu, Tama Gaon Cave, Kabung near Gonpa Kang, Rock Engraving [6].

The potteries/ potsherds retrieved at Gotihawa had been divided into different ceramic classes and separated into rim, bases and walls. These evidences highlight the Nepalese Terai, Utter Pradesh and Bihar. The shape of utensils are Pyala (cups), Katora (bowl), Thali (dishes), Kunda (basins), Borasi (fire holding basin), Katiya (miniature pots), Lohota (Small pots) and other household pots are described. They each maintain a geometrical shape and ritual and religion, culture of people. From this we claim the root of prehistoric man and their mathematics. 


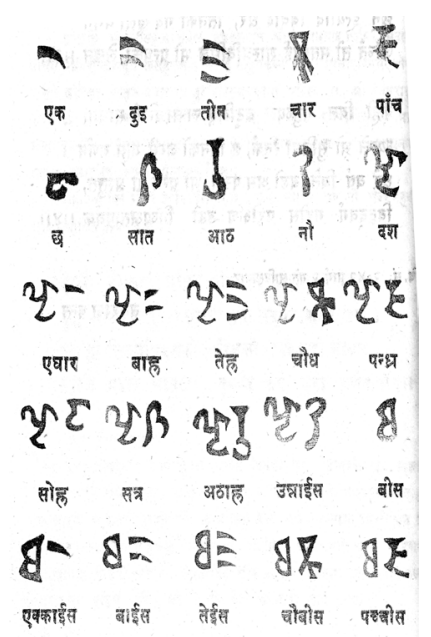

\section{The Words of Numerals in Vedic Period}

The words in an ancient book Vedas are used for counting as, Ek cha me, Tisrascha me Pancha cha me Sapta chame, Navw cha me, Dasha cha me, etc. These words for representing the classical developments in various pillars, monuments support the prehistoric nature of Nepalese mathematics. The symbols in the adjoining figures of numerals for counting in Lichchhavi period expressed by Pant in Prachinkalama Nepalama Chaleko Sankhyalekhanapadhhati show the development of numerical mathematics in Nepal. These evidences justify the existences of prehistoric mathematics in Nepal [9]. BP O The symbols used for the number 386 which are found in Changu Narayan emple. The following Ashoka Pillar Inscription (249 B.C.E) at Lumbini refers to the prehistoric existence of man and their activities in societies. The circle enclosed the word 1/8 (athabhagiye) indicates the mathematical concept [1].

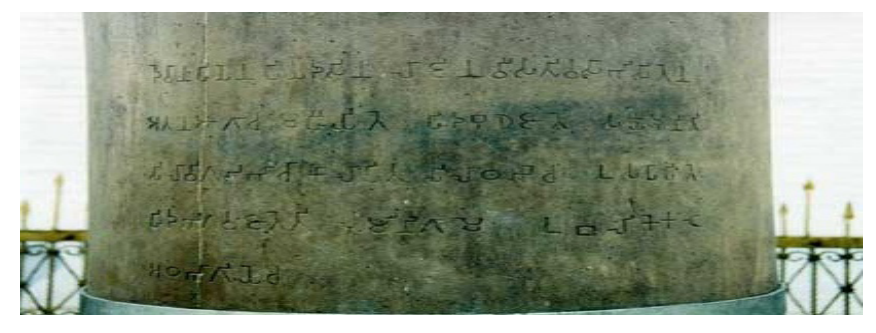

Ashoka Pillar at Lumbini

\section{EVIDENCES NEPALI MATHEMATICS}

The prehistoric domestic instruments like hand axes, bamboo baskets, bamboo caps, wooden cup, potteries of mud, and the fossils of Ramapithecus(at Tinau River, Butwal) etc., are the facts that indicate the existence of prehistoric man. The shapes and sizes of the instruments of stone made axes found in Danda, Charikot, Jung Gaun (Khopasi), Lubhu, Deukhuri and different parts of Nepal are related to mathematics [2].

\section{CONCLUSIONS}

For establishing the concepts of prehistoric mathematics from different reviews with including Clovis and other Paleo-Indian point forms, markers of archaeological cultures in different societies, concluded that the prehistoric mathematical developments are appeared in different part of Nepal. The structuralism is an 

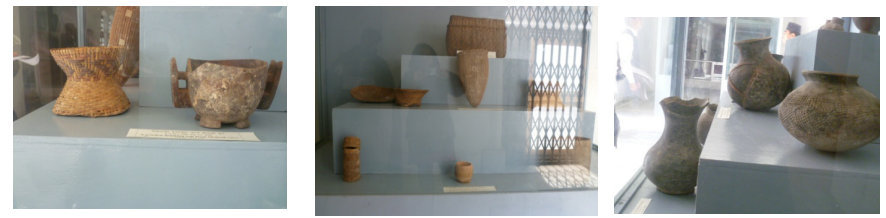

epistemologically realistic view in that it holds that mathematical statements have an objective truth value in early human civilization. On the basis of construction can be claim that the materials obtained from excavation in different regions carry mathematical pattern (mathematical arts, geometric way of thinking). And the existences mathematical pattern imply the existence of prehistoric mathematics. Nepalese mathematics is as old as prehistoric man in Nepal. In each and every ancient civilization, there was the use of arithmetic and geometric as same conditions are available in ancient Nepal. Since mathematics is a practical science which is based on facts of existence. Thus On the basis of above used materials with geometrical shape and their use, conclude the super existence of prehistoric mathematics in Nepal.

\section{ACKNOWLEDGEMENTS}

I am very gratitude to my Prof. Ram Man Shreshtha for suggesting the preparation of this concept paper, constant guidance, untiring help and inspiring support throughout this work and Prof. Dinesh Raj Pant for guidelines and providing resource materials. Also I extend my acknowledgements to Profssors, Surendra Raj Kafle, Bhadra Man Tuladhar, Madan Man Shrestha, Shankar Raj Pant, Santosh Man Maskey, Siddhi Prasad Koirala, Hari Prasad Upadhyay, Min Bahadur Shrestha, Lekhnath Sharma, and Prof. Binod Dhakal.

\section{BiBLIOGRAPHY}

1. Acharya, E. R. (2011), An Analytical Study of Nepalese History of Mathematics: (unpublished Research Report), The Rctor's Office Research Division, Tribhuvan University, Kirtipur, Kathmandu, p.60.

2. Acharya, E. R. \& et al. (2013), Prehistoric Period of Nepali Mathematics (Unpublished Paper presented at A one day seminar on Mathematics Science in Context of Nepal 28 ${ }^{\text {th }}$ Dec.2013).

3. Acharya, Uddhava (2004).Pharping Excavation Report, Ancient Nepal, Government of Nepal, Ministry of Federal Affairs, Constituent assembly Parliamentary, Affairs and Culture, Department of Archaeology, issue 173, pp.11-23.

4. Adhikari, Ankit MUSTANG CAVE: Study leads to peculiar discovery, Kathmandu Post (posted on 2011-1228, down loaded on $13^{\text {th }}$ jan, 2013).

5. A. Simons, W. Schon, Cave Systems and Terrace Settlements in Mustang (1998), Nepal Settlement Periods from Prehistoric Times up to the present Day, AVA-Beitrage 18, pp. 27-47.

6. Darnal, Prakash (2008), Reconnaissance of Caves in upper Lo Mustang, Ancient Nepal, Government of Nepal, Ministry of Federal Affairs, Constituent assembly Parliamentary, Affairs and Culture, Department of Archaeology, issue 166, pp.1-31

7. Gudrun Corvinus, 2007, Prehistoric Cultures in Nepal: From the Early Palaeolithic to the Neolithic and the Quaternary Geology of the Dang-Deokhuri Dun Valleys, 2 volumes, Wiesbaden, Germany: Harrassowitz (in 2 vols. I: 383pp, II: 263pp.

8. Jacqueline T, Eng(2011), Bioarchaeological Report of Upper Mustang, Nepal 2010 Human Remains, Ancient Nepal, Government of Nepal, Ministry of Federal Affairs, Constituent assembly Parliamentary, Affairs and Culture, Department of Archaeology, pp.25-50. 
9. Pant, Dinesh Raj (2010). Numeral System in Ancient Nepal (Paper presented in a Workshop conducted by Nepal Mathematics Centre)

10. Pant, S.R. (2004).Mathematics in Nepal: A historical Analysis, Scientific World (3), Kathmandu: Ministry of Environment, Science and Technology, Government of Nepal,

11. Perdita Pohle Petroglyphs and Abandoned Sites in Mustang: A Unique Source for Research in Cultural History and Historical Geography, Ancient Nepal, pp 1-14.

12. Pradhan, Kedar Nath.(1988), Nepalko Yek Dashamalwo Yek Karod Varshaaghhiko RaamnaravanarNepithecusko Sandarvama Aadimanawako Udgam Ra Udgamasthal, Ancient Nepal, Government of Nepal, Ministry of Federal Affairs, Constituent assembly Parliamentary, Affairs and Culture, Department of Archaeology, issue 106, ( Nepali Khanda, pp.1-17).

13. Prapannacharya (2057 B.S., fifth print), What is in Vedas?, Shajha Prakashan, Lalitpur, pp.103-105.

14. Sharma, Janak Lal (1994), A Brief Note on the Seminar on High Mountain Archaeology of Nepal, Ancient Nepal, Government of Nepal, Ministry of Federal Affairs, Constituent assembly Parliamentary, Affairs and Culture, Department of Archaeology, issue 136, pp.9-15.

15. Shrestha, Khadga Man. (2010), Buddhist Light: Buddhism and Sino-Nepal Cultural Linkage, Ancient Nepal, Government of Nepal, Ministry of Federal Affairs, Constituent assembly Parliamentary, Affairs and Culture, Department of Archaeology, issue 173, pp.1-10.

16. Shrestha, R. M. (2008), mathematics education for the twenty first century new Nepal, Nepal Academy of Science and Technology, Kathmandu, p.107

17. Shrestha, Sukra Sagar and et all. (2009), Climbing into the past: in Archaeology of Mustang, Ancient Nepal, Government of Nepal, Ministry of Federal Affairs, Constituent assembly Parliamentary, Affairs and Culture, Department of Archaeology, issue 171, pp.1-8.

18. Tom Dedroog (Wednesday, December 28, 2011), Ekantipur, Archaeology, Caves, History, Nepal

Citation: E. R. Acharya, Antiquity of Nepali Mathematics American Research Journal of History and Culture Volume 2016; pp:1-10

Copyright (c) 2016 E. R. Acharya, This is an open access article distributed under the Creative Commons Attribution License, which permits unrestricted use, distribution, and reproduction in any medium, provided the original work is properly cited. 